\title{
The Effect of Dividend Policy, Debt Policy, and Asset Growth on Firm Value with Managerial Ownership as Moderating Variables
}

\section{(Empirical Study on Manufacturing Companies Listed on the Indonesian Stock Exchange)}

\author{
*Ranti Nurdiansari ${ }^{1}$, Anis Sriwahyuni ${ }^{2}$, Rizki Apriani ${ }^{3}$, Nur Hidayah K \\ Fadhilah $^{4}$
}

\author{
${ }^{1}$ Student in Nusa Putra University, Sukabumi, Indonesia \\ ${ }^{2}$ Student in Nusa Putra University, Sukabumi, Indonesia \\ ${ }^{3}$ Student in Nusa Putra University, Sukabumi, Indonesia \\ ${ }^{4}$ Lecture in Nusa Putra University, Sukabumi, Indonesia \\ ${ }^{*}$ Corresponding author. E-mail: ranti.nurdiansari_ak18C@nusaputra.ac.id
}

\begin{abstract}
The purpose of this study is to examine the influence of dividend policy, debt policy, and asset growth on firm value in manufacturing businesses listed on the Indonesian Stock Exchange from 2016 to 2020, with managerial ownership serving as a moderating variable. Samples were gathered from 11 of the 184 establishments listed on IDX for this investigation. (1) With a significance threshold of $0.412>0.05$, the study's findings imply that dividend policy has no effect on company value. The findings of this study are comparable to those of [1]. (2) policies that have a negative impact on firm value, with a significance level of $0.001 \mathrm{t}$ table 1.675 , and because policy variables have a negative (-) effect on firm value, (3) growth assets, with a significance level of $0.334>0.05$ and a value of $0.975 \mathrm{t}$ table 1.675. This illustrates that the asset growth variable has no bearing on a business's value. (4) The relationship between dividend policy and firm value is unaffected by managerial ownership. The dividend policy and managerial ownership variables both have a 0.722 level of significance. This finding, which above the significance criterion of 0.05 , implies that managerial ownership has no influence on dividend policy or firm value and that ownership management is incapable of updating the debt policy-firm value relationship. The dividend policy and ownership variables have a combined significance of 0.701 . This value is greater than 0.05 , indicating that ownership has no effect on the relationship between asset growth and business value, and (6) managerial ownership modernizes the relationship between asset growth and business value. The significance levels for dividend policy variables and management ownership are more than 0.05 , indicating that managerial ownership has no effect on the relationship between dividend policy and company value.
\end{abstract}

Keywords: Dividend Policy, Debt Policy, Asset Growth, Managerial Ownership, Firm Value.

\section{INTRODUCTION}

The corporation is a collection of individuals who collaborate to generate commodities that contribute to the broader community's needs. The primary objective is to enhance the well-being of its owners or shareholders, hence increasing the company's value [2]. One technique for achieving corporate goals is to raise the firm's value.
The term "firm value" refers to an investor's assessment of the proportion of a company's performance tied to the traded share. [3]. According to the Indonesian Stock Exchange's (IDX) data, the prevalence of dropping stock prices, which eroded a company's value, fell in 2019. Since the start of the year, the vehicle industry and its components have been cleaned of their share. Since the beginning of the year (year to date/YTD), the various industrial sector, 
which houses the automotive industry and its components, has declined by 7.03 percent, by the manufacturing industry, which continues to shrink due to diminishing demand for automobiles.

The firm with the most depressing shares is PT Indo Kordsa Tbk (BRAM), which has seen its stock price drop by 39.81 percent to $\mathrm{Rp} 6,500$ per share. Meanwhile, PT Multistrada Arah Sarana Tbk (MASA) saw a strengthening of its shares with a 4.35 percent increase to Rp 480/share (CNBC Indonesia, February 06, 2020), and there is one stock that has remained unchanged, namely PT Nipress Tbk (NIPS), which finished at Rp. 282/share. The company was put on hold due to delays in filing financial reports with the Indonesia Stock Exchange (IDX) [4]. Since July 01, 2019, its shares have not been traded.

Investors are the most knowledgeable. Some investors feel that a high stock price equals a high return on investment and that a high stock price equals a sense of pleasure for shareholders. As a result of this satisfaction, shareholder wealth rises. The effective adoption of a high stock price or growth control procedure will help the company better control and manage its cash and assets, resulting in a more profitable product launch.

Several factors affect a company's worth, which is its dividend policy. Dividend policy is described as a strategy for distributing investment money to shareholders in the form of dividends and retained earnings to reinvest the funds in the future. [5].

The debt policy is the second item to consider. The larger the share of debt policies set by the company at a specific level, the higher the firm value.

Asset growth is the third aspect to consider. The level of the entire value of the company's assets each year is called asset growth. Because assets are crucial to your company's operations, the more you have, the better your functional outcomes. [6].

The owner-manager is a manager who actively participates in the firm's decision-making (commissioners, managers, and directors) and has the option of owning stock in the company (shareholders). Increasing management ownership can bring management and shareholder interests closer together, causing managers to act in ways that benefit their shareholders.

Numerous times, research has been undertaken on the company's worth. According to $[6$, profitability increases firm value, institutional ownership decreases substantial value, and asset expansion decreases the strong value. Additionally, dividend policy has little effect on a company's valuation.

This study differs from earlier studies in that management ownership was included as a moderating variable. A mediating variable can make the dependent and independent variables weaker or stronger.

The goal of these studies is to better understand the effects of dividend policy, debt policy, asset growth, and managed assets as moderating variables on company value.

Based on the preceding, the research wishes to rename the phrase "The Effect of Dividend Policy, Debt Policy, and Asset Growth on Firm Value with Managerial Ownership as a Moderating Variable in Manufacturing Companies Listed on the Indonesian Stock Exchange for the 2016-2020 Period".

\section{LITERATURE REVIEW}

\subsection{Signaling Theory}

A signal theory is a good indicator when it comes to financial reporting. Corporations have an incentive to provide information since they know more or better about the company's data and how it will be received by other parties, particularly investors and creditors.

\subsection{Firm Value}

Company values it's a form of company performance born from public trust in the company's business performance through a long journey from its establishment to the present. The firm value represents management's ability to manage company assets.

The value of a business is determined by an investor's assessment of its success, which is typically correlated with the share price [2]. The firm's worth is enhanced by high share prices, which increase market trust in the company's prospects and current performance.

The Price-to-Book Value Ratio is used in this study to depict business value (PBV). When employing the book value (PBV), a firm's value is considered excellent if the PBV is more significant than one (overvalued), that is, if the company's market price exceeds the book value. The greater the $\mathrm{PBV}$, the more effectively the business creates value and grows for its shareholders. If, on the other hand, the PBV is less than one (undervalued), the firm's worth is reduced [7]. 


\subsection{Dividend Policy}

Dividend policy is a critical factor in the wellbeing of shareholders as it relates to generate returns from mutual funds in the form of dividends to shareholders and in the form of accumulated profits that can be redeemed in the future [5]. Dividend policy is a guideline that determines how much of a company's profits to distribute to shareholders as dividends and how much to keep as accumulated dividends. [2].

Based on prior knowledge, the dividend policy is a choice made by the management to either share the company's results with shareholders or to reinvest the company's results in the future for the company's requirements. Because investors prefer dividend income to capital gain, the amount of dividend a company pays can impact its stock price and value.

\subsection{Debt Policy}

Debt policy is a guideline that establishes how much of a business's revenue should be devoted to debt credit needs should be met through debt [7]. Meanwhile, management makes a debt policy to determine the amount of debt, which is a valuable source of funding to finance the company's operations [8].

Based on the above understanding, a debt policy is a financing policy obtained from a third party to finance the company's operations. Financing in debt has benefits such as tax savings, but if the company cannot pay its debts, it will experience a decrease in profits until bankruptcy.

\subsection{Asset Growth}

Asset growth is the change in the balance sheet total that takes the form of increases that the company experiences over a period (one year) [9]. While asset growth is a change percentage in the increase or decrease in the total assets that the company owns [10]. It is expected that the greater the business assets, morehigher the sales performance that the company can achieve. Following an increase in investments, operating performance will further increase trust in the company from outside. Increased confidence in the company by third parties (investors or lenders) affects the credibility of third parties who invest in the company. This is a positive value for investors because it is assumed that increasing company assets will also increase company productivity [6].

\subsection{Managerial Ownership}

The percentage of managers actively involved in making company decisions is known as managerial ownership [13]. If management owns a high number of shares, it can balance the interests of management and shareholders, reducing shareholder-management conflicts. Significant dividend income is also preferred by both direction and shareholders. As a result, the company's worth can be improved because the manager's performance will enhance shareholder prosperity (principals)

\subsection{Hypothesis Development}

\subsubsection{The Effect of Dividend Policy on Firm Value}

The dividend policy refers to management's approach for dividend distribution, which acts as a gauge of the company's prospects. One study demonstrated that variables impacting dividend policy. The following hypothesis is advanced:

H1: Dividend Policy affects firm value.

\subsubsection{The Effect of Debt Policy on Firm Value}

The debt policy obtained from third parties raises the risk of the business, delivering a wrong signal to investors. Excessive leverage increases a company's profitability risk, raising concerns among shareholders about the company's capacity to repay its debts. As a result, the company's net profit declines, and its value plummets. The following hypothesis is based on the previous reasoning:

H2: Debt Policy harms Firm Value.

\subsubsection{The Effect of Asset Growth on Firm Value}

Assets are financial resources with the expectation of future benefits. Increased operational profit and subsequent asset expansion will boost outsider trust in the company [11]. As a result, the company's worth increases. This is consistent with the findings of [12], which indicate that asset expansion has a positive significant effect on a companies value. The following hypothesis is based on the preceding explanation:

H3: Asset Growth has a Positive Effect on Firm Value.

2.7.4. The Effect of Dividend Policy on The Value of The Company Through Managerial Ownership

The percentage of managers active in making company decisions is known as managerial ownership [13]. If management owns a high number of shares, it can balance the interests of management and shareholders, reducing shareholder management conflicts. Significant dividend income is also preferred by both direction and shareholders (a bird 
in the hand theory). As a result, the company's worth can be improved because the manager's performance will enhance shareholder prosperity (principals). This is by the findings of [13], which claim that having a dividend policy reduces the negative link between manager ownership and business value. The hypothesis is as follows, based on the above explanation:

H4: Managerial Ownership through dividend policy positively affects firm value.

\subsubsection{The Effect of Debt Policy on The Value of The Company Through Managerial Ownership}

Debt policy is a term that refers to borrowing money from other parties to fund and invest in business activities. Debt is also inextricably linked to ownership structure and is highly susceptible to changes in business value. When management holds shares, debt is structured optimally, and the company's purpose of increasing its value is supposed to be accomplished. The following hypothesis is based on the preceding explanation:

H5: Managerial Ownership through debt policy has a positive effect on Firm Value.

\subsubsection{The Effect of Asset Growth on Firm Value Through Managerial Ownership}

The managerial capacity of a business to manage its assets influences its worth. Asset growth indicates that a company is operating well and will positively impact its value. [16] investigated this and discovered that management ownership does affect corporate value. The following hypothesis is based on the preceding explanation:

H6: Managerial Ownership through asset growth has a positive impact on Firm Value.

\section{RESEARCH METHODS}

\subsection{Quantitative Approach}

In this research, the approach used is quantitative research. This means that data collection until the research results are in the form of numeric or number systems.

\subsection{Population and Sample}

The population for this study is a manufacturing business that is publicly traded on the Indonesian Stock Exchange. with a total population of 184 companies. From the total population, several companies were taken as samples. The sampling is carried using a purposive sample technique, namely a sampling technique using several criteria. The criteria used include the following:

1) Manufacturing company listed on the Indonesian stock exchange period 2016 to 2020 .

2) Manufacturing company offering full accounts for the period 2016-2020.

3) Financial statements in the rupiah currency.

4) Manufacturers reporting dividend payment periods from 2016 to 2020.

5) Companies whose assets increased between 2016 and 2020.

Eleven companies were used as samples for this study based on these criteria.

\subsection{Data Types and Sources}

This study makes use of panel data. Panel data are a combination of cross-sectional and time-series data. Secondary data, which has been gathered indirectly to augment primary data, is utilized as a data source. The financial statements from the official website of the Indonesia Stock Exchange (www.IDX.co.id) and the website http://emiten.kontan.co.id were utilized as secondary data in this study.

\subsection{Operational Definitions and Measurements of Variable}

\subsubsection{Independent Variable}

The dependent variables are caused or influenced by independent factors (boundary). The following are the independent variables used in this study:

\subsubsection{Dividend Policy}

In this research, it is measured using the Dividend Payout Ratio or DPR, which is calculated by:

Dividend Payout Ratio

$$
=\frac{\text { Dividend Per Share }}{\text { Erning Per Share }}
$$

\subsubsection{Debt Policy}

In this research, it is measured using the Debt to Equity Ratio or DER which is calculated by:

Debt to Equity Ratio $=\frac{\text { Total Debt }}{\text { Total Equity }}$

\subsubsection{Asset Growth}

In this study, asset growth is calculated by: 
Asset Growth

$=\frac{\text { Total Asset } n-\text { Total Asset }(n-1)}{\text { Total Asset }(n-1)}$

\subsubsection{Dependent Variable}

Dependent variables are those that are influenced by another. The dependent variable in this study is the company's valuation. A price-to-book value, or $\mathrm{PBV}$ ratio, is used to approximate a company's value, and it is computed using a formula:

Price Book to Value

$$
=\frac{\text { Price Per Share }}{\text { Book Value Per Share }}
$$

\subsubsection{Moderating Variables}

The moderator variable in this study is management ownership. Administrative ownership is expressed as MOWN calculated using:

MOWN

$=\frac{\text { The Number of Stock Owned Manager }}{\text { Total of the Stock }}$

\subsection{Data Analysis Techniques}

\subsubsection{Classic assumption test}

1) The test of normality determines if the distribution of a mixed or residual variable in a regression model is standard.

2) To determine whether or not the regression model identified a significant relationship.

3) The heteroscedasticity test determines whether the divergence of an observation's residuals from those of other statements in a regression model is unequal.

4) In the linear regression model, the autocorrelation test is performed to determine whether there is a relationship between the mixed error in period $t$ and the mixed error in period $t 1$. [14]

\subsubsection{Hypothesis testing}

1) Simultaneous tests with the F-test are used to confirm the model's validity by examining variabel dependent and independent.

2) Partial testing with the T-test aims to assess the influence of each variable on the dependent variable to clarify the model utilized.

\section{RESULT AND DISCUSSION}

\subsection{Result}

\subsubsection{Classic Assumption Test Results}

Table 1. Result Normality Test

\begin{tabular}{|c|c|c|}
\hline \multicolumn{2}{|c|}{ One-sample Kilmogorov smirnov Test } \\
\hline \multirow{2}{*}{$N$} & $\begin{array}{l}\text { Unstandardized } \\
\text { Residual }\end{array}$ \\
\hline N & 55 \\
\hline \multirow{2}{*}{$\begin{array}{c}\text { Normal } \\
\text { Parameters }\end{array}$} & Mean & 0,00000 \\
\hline \multirow{2}{*}{$\begin{array}{c}\text { Most } \\
\text { Dcxtreme }\end{array}$} & Std. & -212572032 \\
\cline { 2 - 3 } Difference & Absolute & 0,99 \\
\cline { 2 - 3 } & Positive &, 099 \\
\cline { 2 - 3 } & Negatif & $-, 0,97$ \\
\hline \multicolumn{2}{|c|}{ Test Staticric } & 0,99 \\
\hline \multicolumn{2}{|c|}{ Asymp. Sig. (2-tailed) } &, 200 cd \\
\hline
\end{tabular}

The above table shows that the Asymp sig (2tailed) value is $0.200>0.05$, and the data can be said that the data are typically distributed and can be used for research.

\subsubsection{Multicollinearity Test}

Table 2. Result Multicollinearity Test

\begin{tabular}{|c|c|c|c|c|c|c|}
\hline \multicolumn{7}{|c|}{ Coefficients $^{a}$} \\
\hline \multirow{2}{*}{\multicolumn{2}{|c|}{ Model }} & $\begin{array}{c}\text { Unstan } \\
\text { dardiz } \\
\text { ed } \\
\text { Coeffis }\end{array}$ & $\begin{array}{c}\text { stand } \\
\text { ar }\end{array}$ & $\begin{array}{c}\text { Stan } \\
\text { dardi } \\
\text { zed } \\
\text { Coeff }\end{array}$ & \multicolumn{2}{|c|}{$\begin{array}{c}\text { Collineritas } \\
\text { CS }\end{array}$} \\
\hline & & B & $\begin{array}{l}\text { Std. } \\
\text { Error }\end{array}$ & Beta & $\begin{array}{l}\text { Toler } \\
\text { ance }\end{array}$ & VIF \\
\hline \multirow[t]{2}{*}{1} & $\begin{array}{c}\text { (Con } \\
\text { stant } \\
\text { ) }\end{array}$ & 3,713 & ,723 & & & \\
\hline & DPR &, 969 & 1,171 & ,104 & ,962 & 1,03 \\
\hline
\end{tabular}




\begin{tabular}{|c|c|c|c|c|c|}
\hline & & & & & 9 \\
\hline DER & $-1,162$ & 3,28 &,- 447 &, 951 & $\begin{array}{c}1,05 \\
2\end{array}$ \\
\hline PA & 1,307 & 1,341 &, 120 &, 987 & $\begin{array}{c}1,01 \\
3\end{array}$ \\
\hline
\end{tabular}

Because the above table indicates that the dividend policy has a tolerance value of 0.962 , the debt policy has a tolerance value of 0.951 , and the asset growth has a tolerance value of 0.987 . This indicates that the tolerance value exceeds 0.10 . Because the VIF value of each variable exceeds 10, it can be asserted that there is no instance of multicollinearity.

\subsubsection{Heteroscedasticity Test}

Table 3. Glejser Test Results

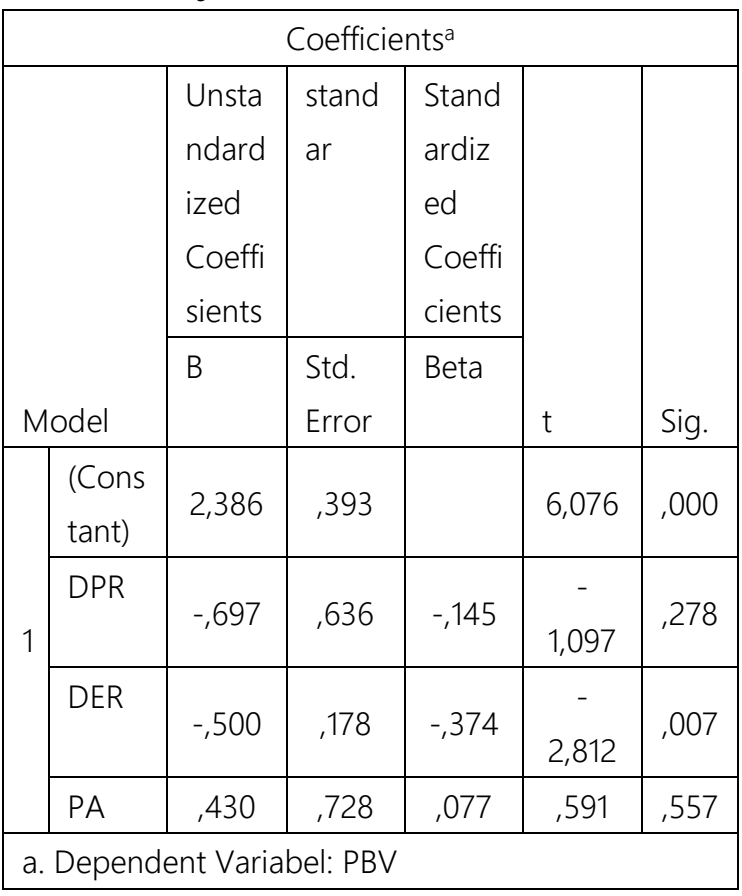

Based on the above data, it can be seen that there is no symptom of heteroscedasticity with significance $>0.05$.

\subsubsection{Autocorrelation Test}

Table 4. Result Autocorrelation Test

\begin{tabular}{|c|c|c|c|c|c|}
\hline \multicolumn{6}{|c|}{ Model Summary } \\
\hline Model & $\mathrm{R}$ & $\begin{array}{c}\mathrm{R} \\
\text { Square }\end{array}$ & $\begin{array}{l}\text { Adjusted } \\
\text { R Square }\end{array}$ & $\begin{array}{c}\text { Std. } \\
\text { Error of } \\
\text { the } \\
\text { Estimate }\end{array}$ & $\begin{array}{c}\text { Durbin } \\
- \\
\text { Watso } \\
n\end{array}$ \\
\hline 1 & $480^{a}$ & ,230 & , 185 & 2,18735 & 1,950 \\
\hline
\end{tabular}

a. Predictors: (Constant), pa, dpr, der

b. Dependent Variable: pbv

From the table above, the results of Durbin Watson are 1.950 , so the value of $\mathrm{du}=1.6815$ is obtained. Value 4-du=2.3185. Therefore, the DurbinWatson value is between the values of du and 4 -du or $\mathrm{du}<\mathrm{d}<4-\mathrm{du} 1.6815<1.950<2.3185$, so there is no corellation

\subsubsection{Hypothesis Test Results}

Table 5. Simultaneous F-Test Results

\begin{tabular}{|c|c|c|c|}
\hline \multicolumn{3}{|c|}{ ANOVA $^{\text {a }}$} \\
\hline \multicolumn{2}{|c|}{ Model } & F & Sig. \\
\hline \multirow{3}{*}{1} & Regression & 5,085 &, $004^{\mathrm{b}}$ \\
\cline { 2 - 4 } & Residual & & \\
\cline { 2 - 4 } & Total & & \\
\hline
\end{tabular}

The computed $\mathrm{F}$ value is 5.085, with a significance of 0.004 , as seen in the table above. This demonstrates how dividend policy, debt policy, and asset growth all impact corporate value.

Table 6. Partial Test T-test

\begin{tabular}{|c|c|c|c|}
\hline \multicolumn{4}{|c|}{ Coefficients $^{\mathrm{a}}$} \\
\hline \multicolumn{2}{|c|}{ Model } & $\mathrm{t}$ & Sig. \\
\hline \multirow{4}{*}{1} & (Constant) & 5,137 & ,000 \\
\hline & DPR & ,827 & 412 \\
\hline & DER & $-3,548$ & 001 \\
\hline & PA & ,975 & ,334 \\
\hline
\end{tabular}

The above table, it shows that:

1) With a significant value of $0.412>0.05$, tvalue of 0.872 , and t-table of 1.675 , the 
influence of dividend policy on firm valuation is tasted.

2) The outputs indicate that debt policy negatively influences firm value, with a significance level of 0.0010 .05 and $t$ value of $-3.548>t$ table of 1.675 .

3) The effect of asset growth on firm valuation was statistically significant at $0.334>0.05$, with t-value of 0.975 and t-table of 1.675 . These findings suggest that the asset growth variable does not affect a company's value.

Table 7. The results of the t-test of the moderating variable

\begin{tabular}{|c|c|c|c|}
\hline \multicolumn{4}{|c|}{ Coefficients $^{a}$} \\
\hline \multicolumn{2}{|r|}{ Model } & $\mathrm{t}$ & Sig. \\
\hline \multirow{4}{*}{1} & (Constant) & 9,306 &, 000 \\
\hline & Man-Dev &,- 357 & ,722 \\
\hline & Man-Hut & ,386 & ,701 \\
\hline & Man-PA & ,200 & ,842 \\
\hline
\end{tabular}

It may be seen from the table above that:

A significance level of $0.722>0.05$, $t$-value of $-0,357$, and $t$-table value of 1.675 indicate that dividend policy affects firm value via management ownership.

1) The significance level for testing influence of debt policy on company value via management ownership is $0.70283>0.05$, the t-value is 0,386 , and the t-table is 1.675 . As a result of these findings, it is reasonable to conclude that the management ownership variable does not sufficiently attenuate the link between dividend policy and firm value.

2) When comparing asset growth to corporate value via management ownership, the significance level is $0.842>0.05$, the $\mathrm{t}$-count is 0,200 , and the $t$-table is 1.675 . As a result of these findings, it is evident that controlled ownership factors are not necessarily positively correlated with asset growth and firm value. The conclusion reached from these outputs is that management ownership variables alone cannot appropriately control the link between a company's value and debt policies.

\subsection{Discussion}

\subsubsection{The Effect of Dividend Policy on The Value of The Company}

H1 asserts company dividend policy affects its value. According to hypothesis testing using the ttest, the dividend policy did not influence corporate value, so $\mathrm{H} 1$ was rejected with a significance value of $0.412>0.05$. This research corroborates [1], who concluded that dividend policy did not affect business value. This supports Miller and Brigham's notion that dividend policy has little effect on company value. This is because the worth of a business is only decided by how it develops assets through its profitability or investment policies.

\subsubsection{The Effect of Debt Policy on The Value of The Company}

H2 that ta company's debt strategy has a detrimental effect on its worth. According to the findings, the debt policy variable has a significance of $0.001 \mathrm{t}$ table 1.675 on the enterprise value. Because the debt policy variable has a (-) influence on the enterprise value, $\mathrm{H} 2$ is assumed. The conclusions of this study are corroborated by studies indicating that debt policy has a detrimental and significant effect on a company's value. In theory, when a company's debt grows, its value increases. The worth of the business can also increase if the pricing is appropriate. The loan proceeds may be utilized to advance the firm's development since this will increase investor profits, and investors will be highly interested in acquiring company shares as a result of the increased investor profits.

\subsubsection{The Effect of Asset Growth on The Value of The Company}

H3 shows that asset growth increases company value. According to the research findings, the significant value of the test asset growth variable to the company value is $0.334>0.05$, and the $\mathrm{t}$ arithmetic value is $0.975 \mathrm{t}$ Table 1.675. As a result, the asset growth variable has no bearing on the firm's value. This is in line with the research findings by [16], which found that asset expansion has no bearing on business value. H3 is therefore rejected. The resource required to run the company's operations may expand as assets grow in value. This is because businesses want to invest profits in the company rather than the wealth of investors or shareholders. As a result, investors lose faith in the firm, which harms its worth, resulting in a fall in its value. 


\subsubsection{The Effect of Dividend Policy on Firm Value Through Managerial Ownership}

According to output regression, the significant value for the dividend policy and management ownership variable is 0.722 . Because this figure is greater than the 0.05 threshold of significance, management ownership does not influence the relationship between dividend policy and company value. As a result, $\mathrm{H} 4$ is considered rejected. This indicates that the amount of dividends paid to the manager does not influence the firm's value. This study corroborates those of 17], who discovered that since internal financing is more efficient than external financing, businesses with a high degree of management ownership will choose to allocate profits to retained earnings rather than dividends. Furthermore, dividend policy is not intended to benefit shareholders, implying that management ownership does not affect the relationship between dividend policy and firm value in this case.

\subsubsection{The Effect of Debt Policy on The Value of The Company Through Managerial Ownership}

According to the regression results, the significance number for the dividend policy variable and managerial ownership is 0.701 . In other words, managerial ownership does not help the link between dividend policy and firm value because it exceeds the 0.05 level of significance. H5 can be regarded to be well rejected based on this. This demonstrates that managerial ownership harms the company's worth. The findings of this research, which says that high

managerial ownership means the company will use less debt, is consistent with [18] studies. In this situation, management ownership does not improve the debt policy in proportion to the company's valuation.

\subsubsection{The Effect of Asset Growth on The Value of The Company Through Managerial Ownership}

The significance number for the dividend policy variable and management ownership is 0.842 in the output regression. The relationship between dividend policy and firm valuation is not affected by managerial ownership, as this value exceeds the 0.05 level of significance. H6 is thus rejected, as may be determined from this. This demonstrates the negative impact of management ownership on business value growth. The output research of [14] is compatible with asset growth being expressed as a difference in total assets from the previous year or a difference in comprehensive support from the current year and the prior year. Every year, the number of assets can fluctuate without affecting the company's value; any decrease or increase in total assets over the research period has no impact on the price per share of equity per share among investors, so asset growth cannot be considered as a factor in investors' investment decisions.

\section{CONCLUSION}

The evidence and discussion support the following conclusions: (1) Dividend policies do not affect a company's value. (2) Debt policy affects a business's value. (3) Asset growth does not affect the project's value. (4) Managerial ownership does not affect the link between dividend policy and business value. (5) Management ownership cannot repair the relationship between debt policy and business value. (6) Management assets are incapable of managing the link between capital growth and enterprise value.

\section{SUGGESTIONS}

The following suggestions can be made based on the discussion and discussion above: (1) It is expected that future studies will add other variables that will have a more significant impact on firm value. (2) Increasing the size of the research sector so that the results are more accurate and represent the situation at the Indonesia Stock Exchange.

\section{REFERENCES}

[1] Y. Y. I Gede, Y. M. Ni Putu, and W. S. Putu, "Pengaruh pertumbuhan aset, profitabilitas, kepemilikan institusional, dan kebijakan dividen terhadap nilai perusahaan," pp. 239249, 2021.

[2] L. Rajagukguk, E. Widyastuty, and Y. Pakpahan, "Analisis Pengaruh Kebijakan Deviden, Struktur Aset, Dan Pertumbuhan Penjualan Terhadap Kebijakan Hutang Pada Perusahaan Manufaktur Yang Terdaftar Di Bursa Efek Indonesia Tahun 2011-2015,” J. Akunt., vol. 17, no. 1, pp. 1-14, 2017.

[3] N. Mubaraq, "Pengaruh Kebijakan Dividen, Kebijakan Hutang, Dan Profitabilitas Terhadap Nilai Perusahaan ( Studi Kasus Perusahaan Manufaktur Yang Terdaftar Di Bursa Efek Indonesia (BEI)," Skripsi Univ. Muhammadiyah Makassar, 2020.

[4] Y. Muamar, "Sektor Manufaktur RI 2019 Lesu, 11 Saham Otomotif Ini Merana," 
CNBC Indonesia, 2020.

[5] Mutmainnah, Z. Puspitaningtyas, and Y. Puspit, "Pengaruh Kebijakan Dividen, Keputusan Investasi, Ukuran Perusahaan Dan Kepemilikan Manajerial Terhadap Nilai Perusahaan,” Bul. Stud. Ekon., vol. 24, no. 1, 5354.

[6] A. Putri and N. F. Asyik, "Pengaruh Struktur Aset, Pertumbuhan Aset, Dan Risiko Bisnis Terhadap Nilai Perusahaan Dengan Struktur Modal Sebagai Variabel Intervening Nur Fadjrih Asyik Sekolah Tinggi Ilmu Ekonomi Indonesia (Stiesia) Surabaya," J. Ilmu dan Ris. Akuntans, vol. 8, no. 3, pp. 1-21, 2019.

[7] H. Purnomo, "Pengaruh kebijakan dividen dan kebijakan hutang terhadap nilai perusahaan dengan kinerja keuangan sebagai variabel moderating," Skripsi Univ. Negei Semarang, 2017.

[8] L. N. Manurung, "Pengaruh Kebijakan Hutang, Struktur Kepemilikan, dan Profitabilitas Terhadap Kebijakan Dividen (Studi Kasus Pada Perusahaan Manufaktur Sektor Barang Konsumsi yang Terdaftar di Bursa Efek Indonesia Tahun 2011-2015)," J. Ilmu dan Ris. Akunt., 2017.

[9] Wahidn, "Analisis Pertumbuhan Aset dan Struktur Modal yang Mempengaruhi Profitabilitas Perusahaan Pada PT. Telekomunikasi Indonesia Tbk.," Skripsi Univ. Islam Negeri Alauddin Makassar, 2018.

[10] M. Novitasari, D. Setiadi, and S. Anwar, "Pengaruh Pertumbuhan Aset Terhadap Profitabilitas Melalui Struktur Modal Studi Kasus PT . Industri Jamu dan Farmasi Sido Muncul Tbk yang terdaftar di Bursa Efek Indonesia Effect of Asset Growth on Profitability Through Capital Structure oleh setiap perusa," J. Investasi, vol. 5 , no. 2 , pp. 13-24, 2019.

[11] I. K. Budiasa, I. Bagus, A. Purbawangsa, and H. Rahyuda, "Pengaruh Risiko Usaha Dan Struktur Modal Terhadap Pertumbuhan Aset Serta Profitabilitas Pada Lembaga Perkreditan Desa Di Kabupaten Badung,” EJurnal Akunt. Univ. Udayana 5.7, vol. 7, pp. 1919-1952, 2016.

[12] N. M. Suastini, I. Bagus, A. Purbawangsa, and H. Rahyuda, "Pertumbuhan Perusahaan Terhadap Nilai Perusahaan Pada Perusahaan Manufaktur di Bursa Efek Indonesia (Struktur Modal sebagai Variabel
Moderasi)," vol. 1, pp. 143-172, 2016.

[13] K. T. Jayanti, P. Eka, D. Marvilianti, and E. Sujana, "Divident Payout Ratio Pada Praktik Peralatan Laba Variabel Moderasi Pada Perusahaan Manufaktur di Bursa Efek Indonesia Tahun 2014-2017," J. Ilm. Mhs. Akunt., vol. 9, pp. 121-132, 2018.

[14] I. Ghozali, "Aplikasi Analisis Multivariate dengan Program IBM SPSS 21 :Update PLS Regresi," Semarang, 2016. 